\title{
Confidentiality versus public duty
}

Anne Savage

J R Soc Med 2006;99:99-100

In 1963 I joined a long established practice in London. About half our patients came from the top of the hill, the rest from Inner London; a good mix. In those days we did our own emergencies and had a flourishing domiciliary midwifery practice, so we were welcomed into peoples' homes at all times of the day and night. In addition, I was Medical Officer to an Infant Welfare Clinic and to an Assessment Home; appointments that caused me to realize that my conventional middle class way of life was not necessarily the norm. Now, looking back on my experiences from the tranquillity of retirement I am bothered by doubts. Ought I, ought anyone with the same sort of experience, to have spoken out more openly. If we had would some of the violence we increasingly see in our homes and on our streets have been prevented. Where does confidentiality end and public duty begin? This is, I suggest, a subject for debate.

We practised from our senior partner's house, hopelessly 'cottage industry' by present day standards but it had advantages. Because the doctor lived round the corner and was a familiar figure in the community nonsense calls were rare and advice given over the telephone was generally well accepted. Home visits, on average 10 a day, were usual and meetings kept to a minimum. Of course there were disadvantages for both patient and doctor; long waiting times for the one, chained to the telephone for the other. And social problems were pressing; dreadful housing conditions, illegal abortions and, for far too many, an endless vista of poverty and hopelessness.

The Infant Welfare Clinic served a multicultural area, a first refuge for successive waves of immigrants arriving mainly from the Indian sub-continent, Africa and the Caribbean bringing their own distinctive cultures and childrearing practices. Fathers rarely made an appearance, though their influence was pervasive and expressed through the mothers. I soon took to asking 'what does his father think' when difficulties with sleeping or feeding came up, and sometimes managed to defuse the tension by producing a 'scientific' answer. Housing and childcare were permanent, intractable problems. Many of the mothers worked but it was a minority that managed to get help from a family member. Another large group worked from home.

London NW3, UK

E-mail: anne@savage2303.freeserve.co.uk
They were isolated and poorly paid but the children seemed contented and the bond between mother and child was almost visible. In the vast majority of households, however, both parents worked, often for long hours, and their children went to 'minders', any old minder because Local Authority regulations were so strict that there were few legal places. My health visitor told me she did not know where 150 of 'her' children were during the day, but from time to time some horror was revealed; six babies in prams in an icy outhouse one winter afternoon for example.

The parents of these children did the best they could for them, but only too often that meant frequent changes. The mechanical nature of much of the care and the perpetual uncertainty upset these bright little toddlers who started to play up and become cheeky and who were then punished by slapping or exclusion. Marital patterns were mixed but marriage itself was often seen as a late recognition of stability, and 'Daddies' changed with bewildering frequency in the early years. Youngsters who were insecure at home became aggressive and disruptive at school and it was these children who later came to occupy most of the places in the Assessment Home.

This was something of a misnomer, because the inmates had reached the end of the line. They had been locked out of their own homes, excluded from school and suffered one foster placement after another-so that by the time they reached 7 or 8 they were hardened, chain-smoking criminals. My job was only to search for nits and deal with sore throats but sometimes, waiting for a child to arrive I would leaf through the notes: they recorded a dismal catalogue of rejection punctuated with exploitation - children put to work illegally for long hours or sold to make pornographic films. Once, wanting to give two lads a taste of normal life, I took them to a Safari Park and one pulled a knife on the other in the back of the car. Fortunately I had another adult with me but we had an uneasy afternoon and I never repeated the experiment.

The Mother and Baby Home had a disproportionate number of girls from the same background, a background of deprivation, I must emphasize, not racial. Except for the occasional 14-year-old from a strict family, ignorance was certainly not a factor; these girls knew more about sexual practices than I did. What they were looking for was love and in many cases the first present they had ever received was a box of chocolates from some lad who had designs of 
his own. 'The only time I feel really happy,' said one girl, 'is when I have a penis inside me' and I am sure that it was not really the orgasm she loved but the enfolding arms. Certainly these girls adored their babies. For the first time in their lives they had encountered undemanding love and they revelled in it. But the toddler stage came only too soon and that they found difficult, when support from professionals had ceased and there was no family to help. 'I hate her' one mother burst out, looking at the curly headed 3 year old. Enquiry revealed the usual repertoire of irritating behaviours such as emptying the contents of the drawers onto the floor, but stuck together in a single room with knocks on the wall if even the mildest rebuke elicited a howl, discipline went by the board. In the past there was almost always a grandparent or aunt round the corner to whom the stricken child could run, who could console and then act as arbiter.

No one who has had even the slightest acquaintance with children can doubt their need for love and acceptance. Babies hold out their arms, toddlers run back from voyages of exploration to throw themselves into waiting laps. My health visitor used to relate how children from some houses she visited ran to meet her with arms outstretched, in the same way as some of them would later run into the arms of paedophiles. The punished child, and offenders must be punished, needs what is now called 'closure', the moment when the sin has been purged and reconciliation achieved. Without that resentment grows together with a distrust of all adults and a grudge against society.

If things were bad then they are worse now. Unreasoning fear of predatory adults has led to admonitions such as 'don't you touch that child'. Even I, a harmless old gran, would now think twice about picking up a child fallen in the street and giving it a hug. Generations have been bred that find the acceptance and companionship they need only in street gangs. At one time this may not have been so important but now the numbers of 'excluded' children have grown, boosted by Anti-Social Behaviour Orders (ASBOs). These junior Mafiosi have taken over whole areas. To them humans of any age are objects to be exploited, so there is fun to be gained from 'happy slapping' and temporary gratification from rape, even of schoolteachers or primary schoolchildren. These youngsters know every aspect of the law and they exploit their knowledge. They are graduating at ever-younger ages to a life of street fighting and crime.

'Born evil' some would say. 'It's genetic' is a more modish explanation, 'I blame the parents' the pub verdict, recently taken up by Downing Street. I cannot shake off the conviction that, in the immortal words of Professor Heinz
Kiosk of Beachcomber fame: 'We are all guilty'. I have seen too much of the pressure on the poor-living always in or on the edge of debt, prey to moneylenders and 'buy now; pay later' merchants - to throw blame around. For many there must be a temptation to agree to 'take a few pictures of your pretty little daughter' or 'give the lad a job and teach him the value of money'. And when even the middle classes find it impossible to stop their children binge drinking or taking drugs what hope have the rest of society? The question of confidentiality has always been a difficult one. I was never, fortunately, in the position of knowingly treating a murderer but the epileptic driver came my way more than once and minor infringements of the law, such as co-habitation and welfare fraud were common. If you are privileged to be invited into other peoples' homes at all hours and are entrusted with their secrets, you do not betray them-but social trends are something different. I felt strongly enough about the housing conditions to consider chaining myself to the Downing Street railingspossible before 'open government' fenced the road off. But I confined myself to writing appealing letters to housing managers who took, I knew, no notice of them. Had I declared publicly 'we are breeding cohorts of hardened criminals' would anyone have listened? Not to me personally, I am sure, but should the profession as a whole unite in highlighting these threats: for threats they are-as serious as microbiological ones?

I am not the first to remark that we have more concern and better protection for our animals than for our children. Those who have rescued dogs from sanctuaries know how vicious they can become and how long it may take to gentle them back into good behaviour. But it can be done. Organizations such as Kidscape and anecdotal evidence suggest that the same may be true for feral children but these initiatives are too few and far between to improve the general situation. We need facts, facts such as only health professionals and social workers can provide as an anonymous 'risk assessment exercise '. Our problem is that in this age of 'evidence-based' research, because it depends for its validity on statistical analysis, large areas of human experience are simply neglected. As a profession we insist on protection by immunization against disease but have failed to shock the authorities into providing the birthrights of every child: loving care, space to run about and a shoulder to cry on. In the countries where this has been done, and I can think of at least two, schools do not need to be protected against vandals, there are few juvenile offenders institutions and citizens of all ages can travel the roads in peace. 